\title{
UJI AKTIVITAS ANTIKOAGULAN PADA SEL DARAH MANUSIA DARI EKSTRAK ALGA COKLAT Turbinaria ornata
}

\author{
(Test of Anticoagulation Activity on Human Blood Cells Extracted From \\ Brown Alga Turbinaria ornata)
}

\author{
Armiyanti Lessy ${ }^{1 *}$, Darus S. Paransa ${ }^{1}$ dan Grevo Gerung ${ }^{1}$ \\ ${ }^{1}$ Program Studi IImu Kelautan, Fakultas Perikanan dan IImu Kelautan, Universitas Sam \\ Ratulangi, Manado
}

*e-mail: lessy_armiyanti@yahoo.com

This study was conducted to determine whether the species is potentially as anticoagulation or coagulation. Tests performed on human blood group $B, O, A B$ and $A$ with 5 treatment respectively. The first treatment is done in human blood as a control; the second treatment with Turbinaria ornata extracted given to human blood; the third treatment with EDTA and Turbinaria ornata extracted given to human blood; fourth treatment with EDTA given to human blood; fifth treatment with ethanol PA given human blood. The results shown that, in the first treatment blood coagulation occur in normal between 8-13 minutes. In the second treatment, blood coagulation occur 8-10 minutes. However, in the third and fourth treatment shown anticoagulation. In the fifth treatment with ethanol PA, blood coagulation occur in 3-4 minutes. In generaly, Turbinaria ornata do not shown as a anticoagulation but human blood coagulation.

Keywords : anticoagulation, blood, extract, Turbinaria ornata

Penelitian ini dilakukan untuk menentukan apakah sepsis Turbinaria ornata berpotensi sebagai antikoagulasi atau koagulasi. penelitian ini menggunakan darah manusia yang diasumsikan tidak memiliki gangguan koagulasi darah. Pengujian dilakukan pada darah manusia golongan darah $B, O, A B$ dan $A$ dan masing masing dengan 5 kali perlakuan. Perlakuan yang pertama dilakukan pada darah sebagai kontrol; Perlakuan ke dua pada darah yang diberi ekstrak Turbinaria ornata; perlakuan ke tiga pada darah yang diberi perlakuan EDTA dan ekstrak Turbinaria ornata; perlakuan ke empat pada darah yang diberikan EDTA; perlakuan ke lima pada darah yang diberikan etanol PA. Pada perlakuan pertama menunjukkan terjadi pembekuan darah pada kategori pembekuan darah normal yaitu antara 8-13 menit. Pada perlakuan ke dua, darah yang diberi ekstrak basah dan kering Turbinaria ornata terlihat membeku antara 810 menit. Pada perlakuan ke tiga, darah yang diberi EDTA dan ekstrak basah dan kering Turbinaria ornata terlihat tidak membeku. Pada perlakuan ke empagt, darah yang diberi EDTA juga tidak membeku. Pada perlakuan ke lima yaitu darah yang diberi etanol PA, terlihat darah membeku pada menit ke 3-4. Sehingga dari pengujian di laboratorium secara in vitro, ekstrak basah dan kering Turbinaria ornata tidak memiliki aktivitas antikoagulasi, tetapi memiliki sifat koagulasi yaitu pembekuan darah.

Kata kunci : antikoagulan, darah, ekstrak, Turbinaria ornata

\section{PENDAHULUAN}

Alga coklat Turbinari ornata merupakan salah satu sumberdaya yang dapat ditemukan terdistribusi di perairan Indonesia dan termasuk dalam golongan Thalophyta yang memiliki kandungan kimia sebagai produk bahan hayati laut antara lain untuk kepentingan farmasitika laut. Potensi farmasitika spesies ini dapat dijadikan biota uji aktivitas antikoagulasi pada darah manusia.

Sanjaya dan Alkatiri (2006), menyatakan bahwa proses koagulasi 
yang terjadi pada pembuluh darah dapat pula menyebabkan banyak resiko berbagai penyakit pada manusia. Proses koagulasi dapat terbentuk melalui pembentukan trombosit dan bekuan fibrin pada tempat cedera sehingga terbentuk pengendalian pendarahan (Kosasih 1982). Proses koagulasi di dalam tubuh dapat diimbangi melalui proses antikoagulasi. Menurut Katzung (2002), pemberian antikoagulasi pada penderita penyakit tromboemboli berfungsi untuk mencegah pembekuan darah dengan jalan menghambat fungsi beberapa faktor pembekuan darah.

Secara in vitro senyawa antikoagulasi yang digunakan untuk mencegah atau mengurangi terjadinya pembekuan darah seperti EDTA (Ethylen diamine tetracetic acid), natrium sitrat, dan heparin (Gandasoebrata 1992). Dalam upaya pengeksplorasian bahan-bahan alam saat ini, khususnya di Sulawesi Utara umumnya masih bersumber dari tumbuhan darat, sedangkan dari tumbuhan laut masih sangat sedikit informasinya. Desa Mokupa Kecamatan Tombariri ketersediaan alga coklat $T$. ornata sangat berlimpah untuk itu eksplorasi bahan sediaan farmasi dari tumbuhan laut mulai digalakan sehingga dapat dimanfaatkan untuk antikoagulasi atau koagulasi. Penelitian ini bertujuan untuk melakukan skrining antikoagulan pada ekstrak basah dan kering alga coklat $T$. ornata secara in vitro.

\section{METODE PENELITIAN}

Lokasi penelitian dilakukan di desa Mokupa kecamatan Tombariri kabupaten Minahasa, seperti terlihat pada Gambar 1.

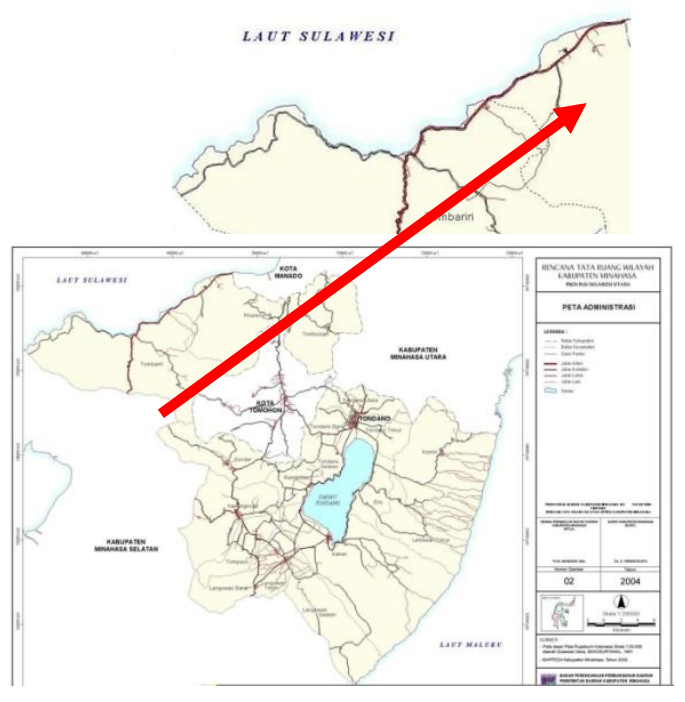

Gambar 1. Peta Lokasi Pengambilan Sampel di Desa Mokupa Kecamatan Tombariri Kabupaten Mianahsa Provinsi Sulawesi Utara.

\section{a. Ekstraksi}

Ekstraksi sampel dilakukan secara maserasi dengan membedakan ekstrak sampel basah dan kering (Posangi 2003). Pada ekstrak sampel basah, 5 gr. T. ornata ditambahkan etanol sebanyak $50 \mathrm{ml}$ dan direndam selama 4 hari. Sedangkan pada ekstrak sampel kering, $10 \mathrm{gr} T$. ornata ditambahkan etanol $50 \mathrm{ml}$. Masing-masing rendaman sampel basah dan kering disaring untuk mendapatkan filtratnya kemudian dievaporasi menggunakan Rotary Vacuum Evaporator sehingga menghasilkan ekstrak kasar.

\section{b. Penyiapan Sampel Uji Darah}

Sebanyak $10 \mathrm{ml} / \mathrm{cc}$ darah $(5 \mathrm{ml} / \mathrm{cc}$ untuk sampel basah dan $5 \mathrm{ml} / \mathrm{cc}$ untuk sampel kering) diambil dari 5 orang relawan

\section{c. Penyiapan Sampel Untuk Pengujian}

Sebelum diujikan pada sampel darah, ekstrak kasar $T$. ornata yang diperoleh dititrasi terlebih dahulu dengan volume ekstrak yang digunakan 
sebanyak $30 \mu \mathrm{l}$. jenis golongan darah yang di ambil yaitu $A, B, A B$, dan $O$.

\section{d. Pengujian Ekstrak Turbinaria ornata Pada Sampel Darah}

Untuk menentukan masa pembekuan darah yang diamati secara visual, digunakan metode Lee-White yang sudah dimodifikasi (Gandasoebrata 1992). Masa pembekuan darah normal pada manusia umumnya terjadi diantara 3-18 menit berdasarkan masa pembekuan darah normal (Bithell 1993). Prosedur kerja metode Lee-White yang sudah dimodifikasi adalah sebagai berikut : Disiapkan 5 buah tabung reaksi dengan diameter $8 \mathrm{~mm}$, yang bersih dan diberi label dari nomor 1 sampai nomor 5 . Darah sebanyak $1 \mathrm{ml}$ dimasukkan kedalam tabung reaksi nomor 1 , stopwatch dilajankan untuk melihat masa pembekuan darah. Pada tabung reaksi nomor 2 dimasukkan darah sebanyak $1 \mathrm{ml}$ dan ekstrak basah dan kering $T$. ornata sebanyak $30 \mu l$ dengan menggunakan mikropipet dan dicampur dengan menggunakan vortex. Waktu yang bersamaan dengan pencampuran, stopwatch dijalankan untuk menentukan masa pembekuan yang terjadi.

Pada tabung reaksi nomor 3 dimasukkan ekstrak basah dan kering T. ornata dan EDTA sebanyak $1 \mathrm{ml}$ kemudian dimasukkan darah sebanyak $1 \mathrm{ml}$ kemudian dicampur dengan vortex, pada saat yang bersamaan waktu dihitung dengan menggunakan stopwatch. Pada tabung reaksi nomor 4 dimasukkan $1 \mathrm{ml}$ darah dan dimasukkan EDTA sebanyak $1 \mathrm{ml}$. EDTA merupakan antikoagulan yang dapat mengikat kalsium sehingga tidak dapat berperan dalam proses pembekuan. Pada tabung reaksi nomor
5, dimasukkan $1 \mathrm{ml}$ darah dan ditambahkan etanol PA kemudian di campurkan dengan fortex. Pada saat yang bersamaan hitung waktu pembekuan darahnya dengan menggunakan stopwatch. Setelah 3 menit tabung diangkat dan masingmasing tabung reaksi dimiringkan untuk melihat apakah sudah terjadi pembekuan atau belum.

Selanjutnya digunakan metode hapusan darah (eustek) untuk melihat efek pembekuan darah secara mikroskopik (Geneser 1994). Sampel yang digunakan pada pengujian ini dipilih pada 1 relawan. Disiapkan 5 kaca obyek yang bersih dan tidak berlemak yang telah difiksasi dalam larutan etanol PA. Masing-masing diberi label nomor 1 sampai nomor 5 . Kaca obyek nomor 1 sampai 5 sama seperti metode Lee-White. Darah dari kaca obyek nomor 1 sampai 5 masingmasing diambil sebanyak $2 \mu \mathrm{l}$. Selanjutnya darah tersebut ditotolkan kemudian diamati di bawah mikroskop tipe SZ2-ILST, dengan pembesaran $40 x$.

\section{HASIL DAN PEMBAHASAN}

Masa aktivitas pembekuan darah $B, A B, A$, dan $O$ dari masing-masing sukarelawan yang tampak pada Tabel 1 yang divisualisasikan pada Gambar 2.

Terlihat 5 buah tabung reaksi dengan jenis golongan darah. Dari kiri ke kanan: tabung Reaksi nomor 1 berisi $1 \mathrm{ml}$ darah (kontrol); tabung reaksi nomor 2 berisi $1 \mathrm{ml}$ darah diberikan $30 \mu \mathrm{l}$ ekstrak $T$. ornata; tabung reaksi nomor 3 berisi $1 \mathrm{ml}$ darah yang diberikan EDTA dan ekstrak $T$. ornata sebanyak $30 \mu$; tabung reaksi nomor 4 berisi $1 \mathrm{ml}$ darah tang diberikan EDTA; dan tabung reaksi nomor 5 berisi $1 \mathrm{ml}$ 
darah yang diberikan etanol PA sebanyak $1 \mathrm{ml}$.

Gambar 2, pada tabung reaksi pertama berisi darah sebagai kontrol dari golongan darah $\mathrm{B}, \mathrm{AB}, \mathrm{A}$, dan $\mathrm{O}$

memiliki masa aktivitas koagulasi yang bervariatif dari menit ke-6 sampai menit ke-10. Hal ini menunjukkan bahwa sampel darah sukarelawan membeku pada batas normal.

Tabel 1. Hasil Pengamatan Masa Aktivitas Koagulasi darah

\begin{tabular}{|c|c|c|c|c|c|c|}
\hline Sampel & $\begin{array}{c}\text { Golongan } \\
\text { Darah }\end{array}$ & $\begin{array}{c}\text { MPDK } \\
\text { (menit) }\end{array}$ & $\begin{array}{c}\text { MPDTO } \\
\text { (menit) }\end{array}$ & $\begin{array}{c}\text { MPDETO } \\
\text { (menit) }\end{array}$ & $\begin{array}{c}\text { MPDE } \\
\text { (menit) }\end{array}$ & $\begin{array}{c}\text { MPDET } \\
\text { (menit) }\end{array}$ \\
\hline \multirow{4}{*}{$\begin{array}{c}\text { Sampel } \\
\text { Basah }\end{array}$} & $\mathrm{B}$ & $03: 40$ & $01: 06$ & $\infty$ & $\infty$ & $01: 36$ \\
\cline { 2 - 7 } & $\mathrm{B}$ & $07: 30$ & $07: 47$ & $\infty$ & $\infty$ & $04: 36$ \\
\cline { 2 - 7 } & $\mathrm{AB}$ & $10: 47$ & $17: 33$ & $\infty$ & $\infty$ & $02: 06$ \\
\cline { 2 - 7 } & $\mathrm{A}$ & $06: 15$ & $04: 31$ & $\infty$ & $\infty$ & $02: 04$ \\
\hline \multirow{4}{*}{$\begin{array}{c}\text { Sampel } \\
\text { Kering }\end{array}$} & $\mathrm{O}$ & $04: 19$ & $05: 40$ & $\infty$ & $\infty$ & $02: 46$ \\
\cline { 2 - 7 } & $\mathrm{B}$ & $06: 15$ & $04: 05$ & $\infty$ & $\infty$ & $02: 52$ \\
\cline { 2 - 7 } & $\mathrm{AB}$ & $07: 42$ & $08: 00$ & $\infty$ & $\infty$ & $02: 56$ \\
\cline { 2 - 7 } & $\mathrm{A}$ & $06: 06$ & $03: 36$ & $\infty$ & $\infty$ & $01: 42$ \\
\cline { 2 - 7 } & $\mathrm{O}$ & $08: 56$ & $05: 15$ & $\infty$ & $\infty$ & $01: 52$ \\
\hline
\end{tabular}

Keterangan:

MPDK : Masa Pembekuan Darah Kontrol

MPDTO : Masa Pembekuan Darah Yang Diberikan Ekstrak T. ornata

MPDETO : Masa Pembekuan Darah Yang Diberikan Ekstrak T. ornata dan EDTA

MPDE : Masa Pembekuan Darah Yang Diberi EDTA

MPDET :Masa Pembekuan Darah Yang Diberikan Etanol PA (darah kontrol)

$\infty \quad$ : Tak terhingga.

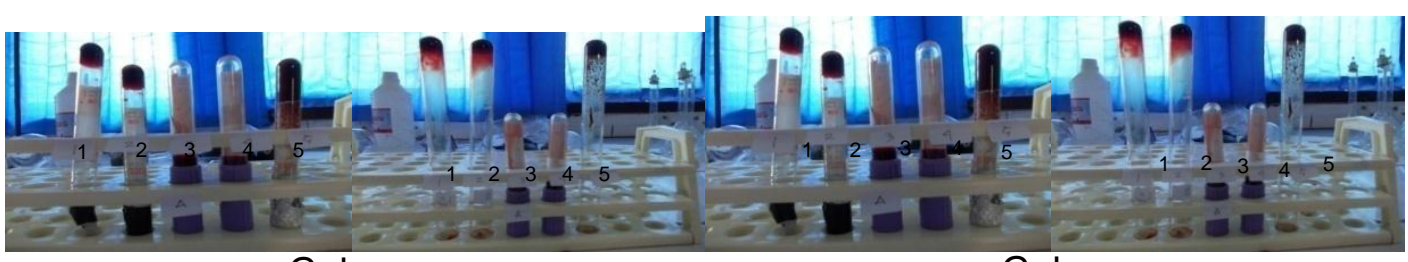
(A)
Golongan
darah B
(B)
(A) darah AB
(B)

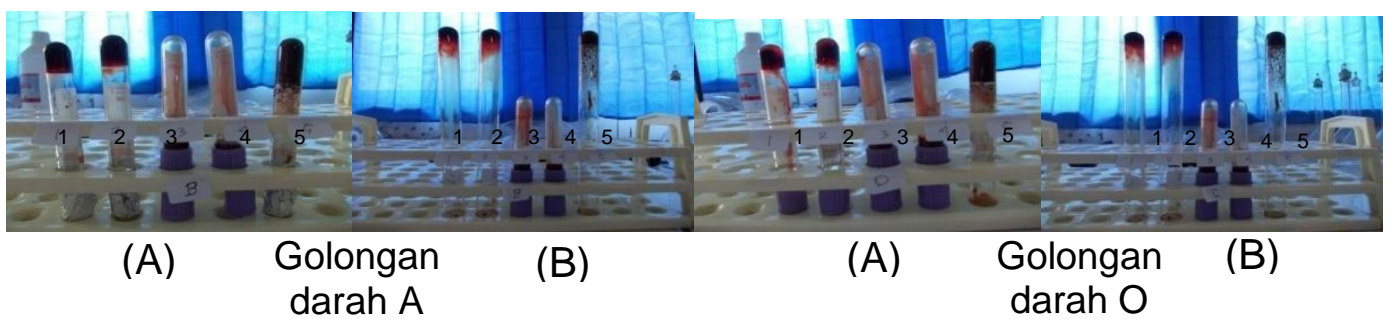

Gambar 2 : Hasil Aktivitas Darah Pada Golongan Darah B, AB, A, dan O Ekstrak T. ornata (A) Ekstrak Sampel Basah

(B) Ekstrak Sampel Kering). 
Tabung reaksi ke-2 (Gambar 2), darah yang ditambahkan ekstrak sampel basah dan kering alga coklat Turbinaria ornata pada golongan darah $B, A B, A$ dan $O$ menunjukkan adanya aktivitas pembekuan darah. Aktivitas pembekuan darah terjadi berkisar diantara menit ke-8 sampai menit ke17. Hal ini menunjukkan bahwa darah dari masing-masing sukarewalan setelah diberikan ekstrak sampel basah dan kering alga coklat $T$. ornata memiliki aktivitas koagulasi.

Pada awalnya penelitian ini, ekstrak sampel basah dan kering alga coklat $T$. ornata diduga memiliki aktifitas antikoagulasi. Dugaan adanya aktivitas antikoagulasi karena menurut Gould dan Lister (2006), senyawa fitokimia golongan pigmen flavonoid dalam dunia kedokteran dimanfaatkan dalam pengobatan, antikoagulasi, antibiotik, antivirus, dan antijamur. Berdasarkan hasil pengamatan Lessy (2012), ekstrak alga coklat $T$. ornata dari Perairan Pantai Mokupa kecamatan Tombariri memiliki pigmen flavonoid.

Pada tabung reaksi nomor 3 dan 4 (Gambar 2), masa pembekuan untuk golongan darah $\mathrm{B}, \mathrm{AB}, \mathrm{A}$, dan $\mathrm{O}$, pada darah yang ditambahkan EDTA dan ekstrak $T$. ornata tidak terjadi pembekuan darah dengan masa pembekuan tak terhingga $(\infty)$. Menurut Widmann (1994), EDTA berfungsi sebagai antikoagulan yang mengikat ion $\mathrm{Ca}^{2+}$ sehingga proses pembekuan darah tidak terjadi.

Pada tabung reaksi nomor 5 (Gambar 2), yang berisi darah dan diberikan etanol PA, terlihat bahwa telah terjadi pembekuan darah pada menit ke-2 sampai menit ke-4 (Tabel 1), untuk masing-masing pendonor. Hasil ini diasumsikan bahwa etanol PA cenderung memiliki aktivitas koagulasi. Darah yang diberikan etanol PA ini, membeku pada masa pembekuan darah normal yaitu 3-18 menit.

Aktivitas pembekuan darah dapat juga dilihat dengan teknik eustek (hapusan darah) yaitu dengan melihat keadaan sel darah secara mikroskopik (Geneser 1994). Sampel darah yang diujikan berasal dari salah satu sukarelawan yang berjenis golongan darah $O$. hasil mikroskop yang menunjukan sel darah setelah diberi perlakuan dapat dilihat pada (Gambar 3).

Ekstrak sampel basah dan ekstrak sampel kering, dimana pada preparat nomor 1 yang merupakan hapusan darah yang tidak diberi perlakuan, tampak sel-sel darah tidak terpisah tetapi saling berikatan satu sama lain. namun tidak mengalami kerusakan. Itu terlihat dari sel-sel darah yang masih utuh. Menurut Sofian (1950) pada darah yang membeku selsel darah melekat satu sama lain.

Preparat nomor 2 (Gambar 4) yaitu darah yang ditambahkan dengan ekstrak Turbinaria ornata menunjukkan hasil yang sama dengan preparat nomor 1, yaitu terjadi pembekuan darah. Tampak sel darah saling berikatan antara satu dan yang lain. Menurut Junqueira dkk (1997), darah dikatakan normal apabila partikel sel darah merah berbentuk bulat-bulat, berdiri sendiri, dengan ukuran yang sama satu dengan yang lainnya.

Preparat nomor 3 dan 4 pada (Gambar 5 dan 6) hasil yang diperoleh yaitu tidak terjadi pembekuan darah. Terlihat sel-sel darah yang tidak berikatan, masih utuh dan terpisah satu dengan lainnya. Hal ini didukung oleh 


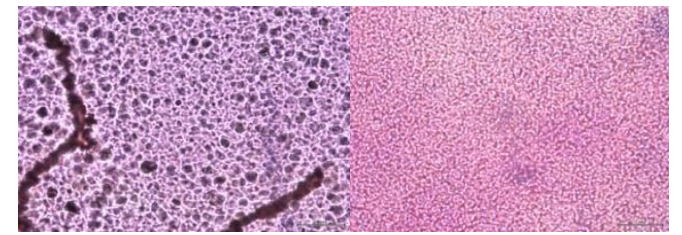

(A)

(B)

Gambar 3. Preparat nomor 1 yang tidak di beri perlakuan. Ekstrak sampel basah (A) ekstrak sampel kering (B).

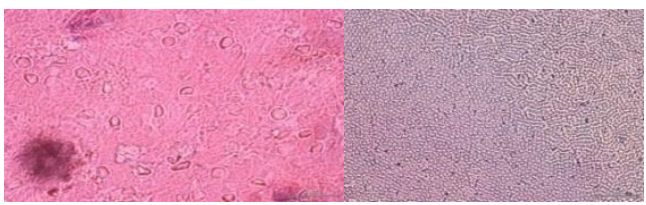

(A)

(B)

Gambar 4. Preparat nomor 2 darah yang diberikan ekstrak Turbinaria ornata sampel basah (A) ekstrak sampel kering (B).

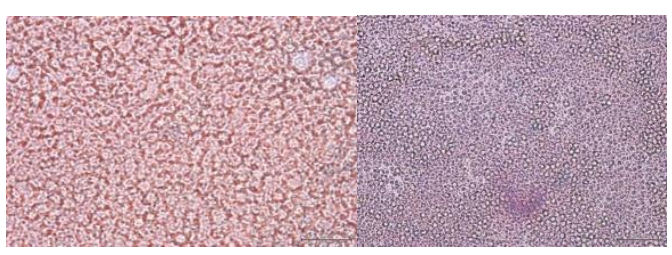

(A)

(B)

Gambar 5. Preparat nomor 3 darah yang diberikan ekstrak Turbinaria ornata dan EDTA sampel basah (A) ekstrak sampel kering (B).

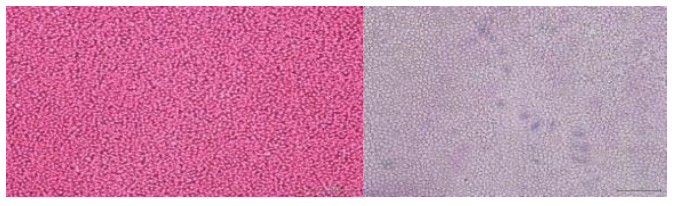

(A)

(B)

Gambar 6. Preparat nomor 4 darah yang diberikan EDTA sampel basah (A) ekstrak sampel kering (B).

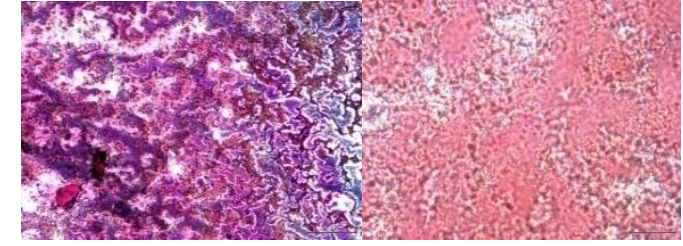

(A)

(B)

Gambar 7. Preparat nomor 5 darah yang diberikan etanol PA sampel basah (A) ekstrak sampel kering (B).

pendapat Junqueira dkk (1997) bahwa pada sediaan hapusan darah yang tidak membeku trombosit tampak berbentuk bulat dan tidak berkelompok serta memiliki inti yang kosong.

Pada preparat nomor 5 (Gambar 7) yaitu darah yang diberi etanol PA, hasil yang diperoleh menunjukkan terjadinya pembekuan darah. Hal yang sama juga diperoleh pada preparat nomor 1 dan preparat nomor 2, tetapi sel darah merah atau eritrosit tidak lagi memiliki bentuk dimana dinding sel hancur. Dimana menurut Pindan (1998), etanol mengandung bahan toksik pada darah, sehingga membran sel darah tidak dapat lagi menahan tekanan dari luar, yang menyebabkan sel darah pecah atau lisis.

\section{KESIMPULAN}

Dari hasil penelitian ini dapat diambil kesimpulan bahwa ekstrak sampel basah dan kering Turbinaria ornata setelah diadakan studi laboratorik secara invitro, hasilnya tidak mempunyai aktivitas antikoagulasi tetapi memiliki aktivitas koagulasi pada golongan darah yaitu $\mathrm{B}, \mathrm{O}, \mathrm{AB}$, dan $\mathrm{A}$. Dengan demikian dapat di rekomendasikan sebagai bahan sediaan farmasi. 


\section{DAFTAR PUSTAKA}

Bithell, T.C. 1993. The Diagnostic Approach To The Bleeding Discordes. In : Lee, R. G,. Bitthell, T. C., Foerster, J., Athens, J. W., Lukens, J. N. ed. Wintrobe's Clinical Hematology. Ninth edition. Malvern, Pennsylvania: Lea and Febiger.

Gandasoebrata, R. 1992. Hematologi. Dalam: Gandasoebrata R. Penuntun Laboratorium Klinik Cetakan Ketujuh. Dian Rakyat. Jakarta.

Geneser, F. 1994. Buku Text Histologi Jilid 1. Binapura Aksara, Jakarta. Binarupa Aksara. 345 hal.

Gould KS, Lister C. 2006. Flavonoid functions in plants. Di dalam: Andersen

OM, Markham KR, editor. FLavonoids Chemistry, Biochemistry and

Applications. Boca Raton, London, New York: Taylor and Francis Group LCC CRC Pres. hlm 397-441.

Junquera, L. C., J. Carneiro, dan R. O. Kelley. 1998. Histologi Dasar Edisi ke-8. Jakarta: Penerbit Buku Kedokteran.

Katzung, B.G. 2002. Farmakologi Dasar dan Klinik. Jakarta: Salemba Medika. 1103 hal.

Kosasih, E.N. 1983. Kelainan Hemostatis KOngenital. Capita Selecta Hematologi Klinik. Alumni, Bandung.

Lessy, A. 2012. Uji Fitokimia Pigmen Flavonoid Pada Alga Coklat. PKL. FPIK. UNSRAT. Manado.

Pindan, A. 1998. Sitotoksik Rhizopora mucronata dan Aktivitas Koagulasinya Dalam Darah
Manusia. SKRIPSI. FPIK UNSRAT. Manado.

Posangi, J. 2003. Ekstraksi: Praktikum Farmakologi dan Terapi. Paket Praktika 04. Bagian Farmakologi dan terapi Fakultas Kedokteran UNSRAT. Manado.

Rosmiati, H. dan V. H. S. Gan. 1995. Antikoagulan, Antitrombotik, Trombolitik dan Hemostatik dalam: Farmakologi dan Terapi. Edisi IV. S. Gan, R. Setiabudi, U. Sjamsuddin, Z.s. Bustani, (editor). Farmakologi FKUI, Jakarta.

Sanjaya, W., dan Alkatiri. A. H. 2006. Sindrom Antifosfolipid dan Trombosis. J. Cermin Dunia Kedokteran 151.hal 42 dan 45.

Sofian, A. 1950. Ilmu Urai Tubuh Manusia. Penerbit Teragung. Jakarta.

Widmann, F. K. 1994. Tinjauan Klinis Atas Hasil Pemeriksaan Laboratorium, Terjemahan Kresno, S. B., R. Gandasoebrata dan T. Latu. EGC. 